\title{
Overproduction and properties of lipase by a wild strain of Burkholderia lata LBBIO-BL02 using chicken fat
}

\author{
Bruno H. Oliveira $\cdot$ Rachid É. Santos $\cdot$ Luiz E. A. Loiola • \\ Valeria M. G. Nascimento
}

Received: 5 April 2014 / Accepted: 3 June 2014 / Published online: 24 June 2014

(C) Springer-Verlag Berlin Heidelberg and the University of Milan 2014

\begin{abstract}
In this work, we report the overproduction of lipases by a new wild strain of Burkholderia lata (LBBIOBL02) in submerged fermentation to seek an economically attractive bioprocess. The best fermentation medium composition was containing chicken fat $(12.5 \mathrm{~mL} / \mathrm{L})$ and ammonium phosphate $(15 \mathrm{~g} / \mathrm{L})$ at $35^{\circ} \mathrm{C}$ and $\mathrm{pH} 7.0$, resulting in a lipase titer of $1137.82 \mathrm{U} / \mathrm{mL}$ and $2146.83 \mathrm{U} / \mathrm{mg}$. The lipase characterization exhibited maximum activity at $55^{\circ} \mathrm{C}$ and $\mathrm{pH} 8.0$. The lipase retained 100,93 and $85 \%$ of its maximum activity at 45,50 and $60{ }^{\circ} \mathrm{C}$, respectively, and 78,82 and $100 \%$ at pH 2.2, 3 and 10, respectively. The enzyme was successfully immobilized on Celite by adsorption and showed a promising future for various organic syntheses because of its stability in organic solvents. All the results shows that Burkholderia lata LBBIO-BL02 is a superior lipase-producing bacterium and its enzyme showed good potential for industrial and biotechnology application.
\end{abstract}

Electronic supplementary material The online version of this article (doi:10.1007/s13213-014-0928-6) contains supplementary material, which is available to authorized users.

B. H. Oliveira • R. É. Santos • L. E. A. Loiola • V. M. G. Nascimento Departamento de Ciências Biológicas, Laboratório de Biotecnologia Industrial, Faculdade de Ciências e Letras, UNESP - Universidade Estadual Paulista Campus de Assis, CEP: 19806-900 Assis, SP, Brazil

B. H. Oliveira • V. M. G. Nascimento

Departamento de Bioquímica e Microbiologia, Instituto de

Biociências, UNESP - Universidade Estadual Paulista, Campus de

Rio Claro, CEP: 13506-900 Rio Claro, SP, Brazil

V. M. G. Nascimento $(\bowtie)$

Laboratório de Bioquímica e Bioprocessos, Depto. de Ciências Biológicas, Universidade Estadual Paulista (UNESP), Campus de Assis, Av. Dom Antônio, 2100, CEP 19806-900 Assis, SP, Brazil e-mail: valeria@assis.unesp.br
Keywords Chicken fat · Lipase - Overproduction · Bioprocess design $\cdot$ Immobilization $\cdot$ Celite

\section{Introduction}

The Burkholderia cepacia complex (Bcc) comprises a group of closely related organisms that occupies diverse ecological niches such as soil, water, animals, plants, and humans. The Bcc strains can be used for multiple applications as bio control, bioprocess, bioremediation, and plant growth promotion purposes, but their capacity as opportunistic bacteria to cause human infections hampers their use in these biotechnological applications (Vanlaere et al. 2009; Lipuma 2010). The Burkholderia lata species was differentiated from Bcc in 2009 (Vanlaere et al. 2009). According to a recent research describing Bcc species that are involved in respiratory tract infection in cystic fibrosis, the $B$. lata strains was not cited as a pathogen (Lipuma 2010). There are no records in the literature using this bacteria in biotechnology studies.

$\mathrm{Bcc}$ is an important group in the current research on biotechnology. Lipases from the Bcc strains shows biocatalysis capability in organic solvents media and are used in biofuel production, chiral reactions for pharmaceutical products, and racemic resolutions (Kawakami et al. 2011; Li et al. 2013), which make them attractive for the applications in diversified industrial sectors. Despite this, the industrial use of lipases is limited by the high cost of its production and the necessary purity grade according to its use. Because of this, finding a new strain with an overproducing lipase and the potential of using low cost nutrients such as agro-industrial residues and inorganic salts in microbial fermentation for enzyme production are extremely important in dictating future uses of lipases. 
Medium optimization for overproduction of the enzyme is an important step for its commercial usage and involves a number of physico-chemical parameters such as the composition of production medium, the carbon and nitrogen sources, minerals and trace metals, $\mathrm{pH}$, temperature, aeration, and inoculum age (Jaeger et al. 1994; Gupta et al. 2004). One of the most critical factors in producing microbial lipases is the choice of carbon sources as enzyme inducers. Compounds such as plant seed oils (triacylglycerols), free fatty acids, surfactants, bile salts and glycerol have been included in the nutrient medium to increase levels of lipase activity (Gupta et al. 2004). Olive oil has frequently been cited as an inducer of Bcc lipases (Boekema et al. 2007); however, vegetable oils are regarded as expensive fermentation substrates and are mainly used as a food stock.

Animal fat has the advantages of wide availability and low cost, and waste meat processing. Chicken fat is disposed by the poultry processing industry (Arnaud et al. 2004), which has been used to produce biodiesel; however, it can also be used for obtaining bioproducts with high added value such as enzymes. The average cost of the disposal is of US $\$ 0.55 / \mathrm{L}$, against US $\$ 3.15 / \mathrm{L}$ of olive oil (2014).

The use of pure enzymes in biotechnology can be costly and its disposal after reaction is uneconomical. Furthermore, recovery of the reaction medium may be difficult. The development of immobilization techniques have been important for providing reuse of enzymes to facilitate separation of products and increase stability in organic solvents (Chang et al. 2007). As an inert support material, Celite ${ }^{\circledR} 545$ consists of highly porous diatomaceous earth beads composed of more than $90 \%$ silica $\left(\mathrm{SiO}_{2}\right)$ with a superficial area of $2.19 \mathrm{~m}^{2} / \mathrm{g}$ (SIGMA). Because of its chemical inertness and interconnected pore structure (Chang et al. 2007), Celite ${ }^{\circledR} 545$ is very suitable for enzyme immobilization by physical adsorption. There is a growing interest in the use of Celite beads as immobilization support material to enhance reaction rates by providing a better distribution of the catalyst (Mateo et al. 2007; Chang et al. 2007), besides the economic advantages of enzyme reutilization.

The present study was started with the aim of developing an efficient and economic fermentation media for overproduction of lipase by a new Bcc specie Burkholderia lata LBBIOBL02. Besides the production, this work evaluated the enzyme properties of free and immobilized Celite ${ }^{\circledR} 545$.

\section{Material and methods}

Strain identification

The bacterial strain LBBIO-BL02 was isolated in our laboratory in a fungal culture contamination and identified by morphological and molecular methods (16S RNA) at Fundação André Tosello (FAT), Campinas - SP - Brasil.

Production of lipase in submerged fermentation $(\mathrm{SmF})$

The bacteria cultivation was started with a pre-inoculum in $250 \mathrm{~mL}$ Erlenmeyer flasks containing $50 \mathrm{~mL}$ of Luria-Bertani (LB) medium with an incubation time of about $48 \mathrm{~h}$ (until the order of $10^{8}$ cells $/ \mathrm{mL}$ ) at $30^{\circ} \mathrm{C}$ and with $180 \mathrm{rpm}$ orbital shaking. After this, $1 \mathrm{~mL}$ of the culture was passed to $250 \mathrm{~mL}$ Erlenmeyer flasks containing $50 \mathrm{~mL}$ of fermentation medium maintained under the same conditions. The standard fermentation medium was composed of $\mathrm{K}_{2} \mathrm{HPO}_{4}(1.0 \mathrm{~g} / \mathrm{L})$, $\mathrm{MgSO}_{4} \cdot 7 \mathrm{H}_{2} \mathrm{O}(0.5 \mathrm{~g} / \mathrm{L}), \mathrm{NaCl}(0.38 \mathrm{~g} / \mathrm{L})$ and $\mathrm{FeSO}_{4} \cdot 7 \mathrm{H}_{2} \mathrm{O}(0.01 \mathrm{~g} / \mathrm{L})$. The $\mathrm{C}$ and $\mathrm{N}$ sources varied according to the assay. Bacterial growth was monitored during the cultivation by counting cells in a Neubauer chamber.

\section{The effect of different $\mathrm{C}$ and $\mathrm{N}$ sources}

For lipase production by $B$. lata in $\mathrm{SmF}$ was evaluated with chicken fat or different oil sources: olive, corn, soybean, crambe, palm, and linseed $(10 \mathrm{~mL} / \mathrm{L})$.

To study the influence of $\mathrm{N}$ sources in the lipase production by $B$. lata, we studied six different organic and inorganic $\mathrm{N}$ sources using a $2^{6-2}$ fractional design method (Table 2). The $\mathrm{N}$ sources evaluated were yeast extract, urea, ammonium sulfate, sodium nitrate, ammonium nitrate, and ammonium phosphate. The chicken fat $(10.0 \mathrm{~mL} / \mathrm{L})$ was used as a carbon source. Table 2 shows the independent factors (Xi), their levels, and experimental design in terms of coded $(-1,0$, and +1$)$ and non-coded (actual value) variables.

The influence of the concentrations of the $\mathrm{C}\left(\mathrm{X}_{1}\right)$ and $\mathrm{N}$ $\left(X_{2}\right)$ source were investigated by a 2-level, 2-factor factorial design requiring 12 experiments with four central points and four axial points. The variables and their levels selected for lipase production were $\mathrm{C}(0.0-25.0 \mathrm{~mL} / \mathrm{L})$ as $\mathrm{N}$ source $(0.0$ $12.0 \mathrm{~g} / \mathrm{L})$. Table 4 shows the independent factors $\left(\mathrm{X}_{\mathrm{i}}\right)$, their levels, and the experimental design in terms of the coded $(-\alpha$, $-1,0,1$, and $+\alpha$ ) and the non-coded (actual value) variables. The analyses were performed using STATISTICA 8.0 software (Statsoft Inc.) to calculate the main effects of the variables, their interactions, and to perform the analysis of variance (ANOVA).

The response of variables, $Y$ (lipase activity, $\mathrm{U} / \mathrm{mL}$ ), may be approximated by the polynomial equations:

\section{$\mathrm{CCD} 2^{2}$ :}

$Y=\beta_{0}+\sum \beta_{i} x_{i}+\sum \beta_{i i} x_{i}^{2}+\sum \beta_{i j} x_{i} x_{j}$ 
where: $\mathrm{Y}$ is the predicted response, $\beta_{0}$ is the offset term, $\beta_{i}$ the linear effect, $\beta_{i i}$ the squared effect, and $\beta i j$ the interaction effect.

Effect of the temperature and initial $\mathrm{pH}$ on lipase production

The effect of initial culture $\mathrm{pH}$ on lipase production was studied using univariate study in shake flasks at different initial $\mathrm{pH}$ values ( $\mathrm{pH} 3$ to 12). The $\mathrm{pH}$ of the medium was adjusted to the desired value by using either $1 \mathrm{~mol} / \mathrm{L} \mathrm{NaOH}$ or $1 \mathrm{~mol} / \mathrm{L} \mathrm{HCl}$ prior to the sterilization process.

Temperatures ranging from 30 to $45{ }^{\circ} \mathrm{C}$ were tested for their effect on lipase production by B. lata with 48 and $72 \mathrm{~h}$ of fermentation.

\section{Enzyme biochemical characterization}

To determine the $\mathrm{pH}$ effect on the lipase activity of the crude extract, assays were performed varying the reaction medium $\mathrm{pH}$ between $\mathrm{pH} 2.3$ and 10 . The method had to be adapted as described below, because $p$-nitrophenol ( $p \mathrm{NP}$ ) doesn't absorb color below $\mathrm{pH}$ 6.0. The reaction was carried out in tubes with $4.5 \mathrm{~mL}$ of reaction medium pre-equilibrated at $37{ }^{\circ} \mathrm{C}$. After adding $0.5 \mathrm{~mL}$ of enzyme solution, $0.1 \mathrm{~mL}$ aliquots were removed, added to $0.9 \mathrm{~mL}$ of phosphate buffer $0.05 \mathrm{~mol} / \mathrm{L}$ $\mathrm{pH} 8.0$ and transferred to an ice bath. The activities were calculated based on the concentration of product in $1 \mathrm{~min}$ using the molar extinction coefficient determined at $\mathrm{pH}$ 8.0.

The $\mathrm{pH}$ stability was determined by incubating crude extract in buffers with $\mathrm{pH}$ values from 2.3 to 10 for $1 \mathrm{~h}$ at room temperature. After incubation, residual activity was determined using phosphate buffer $0.05 \mathrm{~mol} / \mathrm{L} \mathrm{pH} 8.0$ by the standard method.

To determine the effect of temperature on the enzyme activity, the enzymatic reaction was carried out at temperatures between 20 and $90^{\circ} \mathrm{C}$, in phosphate buffer at $0.05 \mathrm{~mol} / \mathrm{L}$ $\mathrm{pH} 8.0$.

The temperature stability was determined by incubating the enzyme extract at temperatures between 20 and $70{ }^{\circ} \mathrm{C}$ in the absence of substrate. Residual lipase activity was determined at $37^{\circ} \mathrm{C}$ by the standard method.

Immobilization by adsorption on Celite ${ }^{\circledR} 545$ and stability in organic solvents

The immobilized enzyme on Celite ${ }^{\circledR} 545$ was prepared as described by Chang et al. (2007) with modifications. In $5 \mathrm{~g}$ of support was added $5 \mathrm{~mL}$ of enzyme followed by addition of $50 \mathrm{~mL}$ of isopropanol at $-10^{\circ} \mathrm{C}$. The mixture was homogenized under gentle agitation and immobilized lipase was collected by filtration and washed twice with $\mathrm{n}$-hexane to remove non-adsorbed impurities and enzyme.
The FT-IR spectra of Celite-545, free lipase, and Celite-545 adsorbed lipase were recorded on a Bruker Tensor 37 FTIR spectrometer using the potassium bromide pellet method. The pellets were prepared from a mixture of $200 \mathrm{mg}$ potassium bromide, $3 \mathrm{mg}$ of the samples, and $1.5 \mathrm{mg}$ potassium ferricyanide as an internal standard. The acquisition conditions were: spectral width 4000 to $500 \mathrm{~cm}^{-1}, 32$ accumulations, and $4 \mathrm{~cm}^{-1}$ resolution.

To determine the stability of lipolytic activity of free and immobilized enzyme in polar organic solvents, methanol, ethanol, isopropanol, and acetone were used in different concentrations $(25,50,75$, and $100 \%, v / v)$ in incubation for $1 \mathrm{~h}$ at room temperature. The residual activity was determined according to the standard method.

Analytical methods

\section{Lipase activity determination}

The hydrolysis of $p$ NPP was used to follow the trials of fermentation and biochemical characterization. The lipase activity was measured by the hydrolysis of $p$-nitrophenyl palmitate ( $p$ NPP) as first described by Winkler and Stuckmann (Winkler and Stuckmann 1979). One unit of lipase activity is defined as the release of $1 \mathrm{mmol} / \mathrm{min}$ of $p$-nitrophenol $(p \mathrm{NP})$. The molar extinction coefficient of $p$ NP $(1.5 \times$ $\mathrm{s} 10^{4} \mathrm{~mol} / \mathrm{L} \mathrm{x} \mathrm{cm}$ ) was used to correlate the concentration of product from the absorbance readings.

The lipase activity determination by titration was used for characterization of enzymatic activity against natural substrates and triacylglycerols of different chain sizes. The reaction medium consisted of $0.2 \mathrm{~mol} / \mathrm{L}$ of substrate, $6 \%(\mathrm{w} / \mathrm{v})$ of Triton X-100, and $74 \%(\mathrm{v} / \mathrm{v})$ citrate-phosphate buffer $0.05 \mathrm{~mol} / \mathrm{L} \mathrm{pH} \mathrm{7.0.} \mathrm{To} \mathrm{this} \mathrm{was} \mathrm{added} 1 \mathrm{~mL}$ of lipase to $5 \mathrm{~mL}$ of enzyme reaction medium and with incubation for $30 \mathrm{~min}$ at $55^{\circ} \mathrm{C}$ under strong agitation $(300 \mathrm{rpm})$. After incubation, $16 \mathrm{~mL}$ of a $1: 1(\mathrm{v} / \mathrm{v})$ mixture of acetone and ethanol was added and this solution was titrated with $\mathrm{NaOH}$ $0.1 \mathrm{~mol} / \mathrm{L}$. One unit of enzyme activity was equivalent to $1 \mathrm{mmol}$ of fatty acid released per minute.

\section{Protein concentration assay}

Protein concentration was determined according to the procedure described by Bradford (Bradford 1976) using BSA as a standard protein.

\section{Gas chromatography (GC) analysis of fatty acids}

The fatty acid derived from chicken fat were identified at Technology Laboratory of Animal Products (UNESP Jaboticabal/SP) by GC using a Shimadzu 14B Gas Chromatograph connected to a OMEGAWAX250 capillary column 
(30 $\mathrm{m} \times 0.25 \mathrm{~mm} \times 0.25 \mu \mathrm{m})$. The injector and detector temperatures were set at 250 and $280{ }^{\circ} \mathrm{C}$, respectively. The column temperature was initially maintained at $100{ }^{\circ} \mathrm{C}$ for $2 \mathrm{~min}$, increased to $220{ }^{\circ} \mathrm{C}$ at $4{ }^{\circ} \mathrm{C} / \mathrm{min}$, and finally held at $300^{\circ} \mathrm{C}$ for $25 \mathrm{~min}$. A mix of fatty acids (SIGMA) was used as standard.

\section{Results}

Strain identification

Morphologically, the strain introduced in the form of large Gram-negative bacilli and the sequencing of the 16S RNA, allowed the identification of the strain as Burkholderia lata. The strain was deposited at the culture collection of the Faculdade de Ciências e Letras de Assis - UNESP/Assis under LBBIO-BL02 code. This species was differentiated from Burkholderia cepacia complex (Bcc) in 2009 (Vanlaere et al. 2009), and there are no records in the literature of lipase production by this strain.

Production of lipase in submerged fermentation

\section{The effect of different carbon sources}

Throughout the study, the cultures with our $B$. lata LBBIO-BL02 strain had markedly high lipolytic activity, volumetric and specific, presenting unusual values in comparison with the literature. With the exception of fermentation with linseed oil, all other carbon sources produced lipase above $150 \mathrm{U} / \mathrm{mL}$. Chicken fat showed the highest lipase activity $(323 \mathrm{U} / \mathrm{mL})$ and the highest specific activity (1619 U/mg) compared to other sources (Table 1). Specific activity above $1000 \mathrm{U} / \mathrm{mg}$ was also obtained with olive and corn oils.

Although chicken fat is an animal fat, the analysis of its fatty acids composition found a high percentage of oleic, linoleic, and linolenic acids (57\%), similar to vegetable oils traditionally used in lipase production by microorganisms. The contents of these fatty acids has been linked to induction of enzyme production, which may explain the good results obtained with chicken fat.

Beyond inducing the increased production of the enzyme, chicken fat provided the best Production cost/Lipase activity rate, defined as the best carbon source for stimulating lipase production by Burkholderia lata strain with high enzyme production at low cost (Table 1). Moreover, it is interesting to note that Production cost/Lipase activity rate is even competitive with other carbon sources, such as corn, soybean, crambe, and palm oils.

\section{The effect of different $N$ sources}

To study the effect of different $\mathrm{N}$ sources, organic and inorganic, a fractional design $2^{6-2}$ was performed. In this study, the highest enzyme activities was found in experimental run 9 using sodium nitrate $\left(\mathrm{X}_{4}\right)$ and ammonium phosphate $\left(\mathrm{X}_{6}\right)$, with lipase activity of $373.0 \mathrm{U} / \mathrm{mL}$ and $4696.29 \mathrm{U} / \mathrm{mg}$ (Table 2). The specific activity obtained in this experiment has no precedent in the literature. Inorganic nitrogen sources were found to increase lipase synthesis by $B$. lata grown in the presence of chicken fat. From the analysis of the effects, it was possible to observe that only $\mathrm{X}_{6}$ was significant to a confidence level of $p<0.05$ with a positive influence (Table 3 ). Therefore, ammonium phosphate was chosen for the sequence of experiments. Besides being the $\mathrm{N}$ source to induce increased production of the enzyme, the salt ammonium phosphate is at a lower cost than organic sources, and its presence hinders subsequent stages of protein purification.

\section{Carbon and nitrogen concentrations}

The results show the importance of chicken fat and ammonium phosphate to produce lipase by B. lata. However, the concentration of these nutrients requires evaluation, and there is the possibility of interaction between them. Since the conventional method (one factor at a time) used for optimization does not indicate the interactions between the significant components, a statistical approach for optimizing the significant media components has been employed.

In the experimental design performed, there were obtained lipolytic activities ranging from 0.06 to $425.00 \mathrm{U} / \mathrm{mL}$. The highest activity was observed in Experiment $8(425.00 \mathrm{U} / \mathrm{mL})$, which included the largest concentration of the nitrogen source $(0, \alpha+)$. Table 4 describes the planning matrix, with its coded variables, and the predicted and observed results.

Considering the volumetric activity obtained in the experiments, based on the analysis of the effects, the interaction between $\mathrm{X}_{1}$ (oil chicken) and $X_{2}$ (ammonium phosphate) was not significant at a confidence level of $p<0.05$ (Table 5). However, the isolated variables had significant effects. Thus, the concentrations of $\mathrm{C}$ and $\mathrm{N}$ sources have positive influences on the response, that is, increasing these variables will increase the value of enzyme activity causing an average activity increase of 115.5 and $304.8 \mathrm{U} / \mathrm{mL}$ when passing level (-) to level (+), respectively.

Considering the specific activity obtained in the experiments, the concentration of ammonium phosphate has a significant influence, providing an average increase of 1064 $\mathrm{U} / \mathrm{mg}$ when passing from level $(-)$ to the level $(+)$. The concentration of the carbon source had no significant effect on specific activity.

The $\mathrm{F}$ test demonstrated that for the variables studied, $\mathrm{F}_{\text {calc }}>_{\mathrm{Ftab}}$ (Table 5) was meaningful, and the model was valid. 
Table 1 Influence of different oils and fat as carbon sources on lipase production by B. lata in SmF

\begin{tabular}{|c|c|c|c|c|c|c|c|c|}
\hline \multirow[t]{2}{*}{ Substrate } & \multirow{2}{*}{$\begin{array}{l}\text { Lipase activity } \\
(\mathrm{U} / \mathrm{mL})\end{array}$} & \multirow{2}{*}{$\begin{array}{l}\text { Production cost/Lipase activity* } \\
\text { (\$/million units) }\end{array}$} & \multirow{2}{*}{$\begin{array}{l}\text { Specific activity } \\
\text { (U/mg) }\end{array}$} & \multicolumn{5}{|c|}{ Fatty acids content of $\mathrm{C}$ sources } \\
\hline & & & & $\begin{array}{l}\text { Oleic } \\
\left({ }^{\Delta 9} 18: 1\right)\end{array}$ & $\begin{array}{l}\text { Linoleic } \\
\left({ }^{\Delta 9,12} 18: 2\right)\end{array}$ & $\begin{array}{l}\text { Linolenic } \\
\left({ }^{\Delta 9,12,15} 18: 3\right)\end{array}$ & $\begin{array}{l}\text { Erucic } \\
\left({ }^{\Delta 13} 22: 1\right)\end{array}$ & $\begin{array}{l}\text { Palmitic } \\
(16: 0)\end{array}$ \\
\hline Chicken fat & $323.81 \pm 43.17$ & 0.02 & 1619.05 & 43 & 14 & 0.7 & - & 25 \\
\hline Corn oil & $258.44 \pm 19.21$ & 0.05 & 1292.20 & 35 & 45 & 1 & - & 10 \\
\hline $\begin{array}{l}\text { Soybean } \\
\text { oil }\end{array}$ & $207.66 \pm 23.75$ & 0.05 & 988.86 & 21 & 54 & 6 & 0.3 & 11 \\
\hline Olive oil & $207.12 \pm 34.08$ & 0.14 & 1218.35 & 70 & 10 & 0.2 & - & 16 \\
\hline $\begin{array}{l}\text { Palm oil } \\
\text { (dendê) }\end{array}$ & $202.35 \pm 7.21$ & 0.06 & 249.81 & 40 & 17 & - & - & 34 \\
\hline Crambe oil & $187.10 \pm 20.33$ & 0.04 & 668.21 & 18 & 9 & 6 & 56 & 2 \\
\hline Linseed & $8.23 \pm 2.92$ & 1.52 & 30.48 & 11 & 15 & 40 & - & 2 \\
\hline
\end{tabular}

*Commercial value of the carbon sources was obtained from the Agricultural Marketing Resource Center (USDA Economic Research Service 2014)

Table 2 Fractional design matrix (factorial $2^{6-2}$ ) containing four repetitions at the central point for the production of lipase by $B$. lata in $\mathrm{SmF}$

\begin{tabular}{|c|c|c|c|c|c|c|c|c|}
\hline \multirow[t]{2}{*}{ Run } & \multicolumn{6}{|c|}{ Variables in coded levels } & \multicolumn{2}{|l|}{ Response } \\
\hline & $\mathrm{X}_{1}$ & $X_{2}$ & $\mathrm{X}_{3}$ & $\mathrm{X}_{4}$ & $\mathrm{X}_{5}$ & $\mathrm{X}_{6}$ & $Y(\mathrm{U} / \mathrm{mL})$ & Specific Activity (U/mg) \\
\hline 1 & -1 & -1 & -1 & -1 & -1 & -1 & 0.47 & 13.74 \\
\hline 2 & 1 & -1 & -1 & -1 & 1 & -1 & 6.08 & 138.34 \\
\hline 3 & -1 & 1 & -1 & -1 & 1 & 1 & 22.47 & 355.64 \\
\hline 4 & 1 & 1 & -1 & -1 & -1 & 1 & 59.33 & 933.29 \\
\hline 5 & -1 & -1 & 1 & -1 & 1 & 1 & 11.03 & 282.94 \\
\hline 6 & 1 & -1 & 1 & -1 & -1 & 1 & 28.83 & 190.35 \\
\hline 7 & -1 & 1 & 1 & -1 & -1 & -1 & 5.92 & 50.74 \\
\hline 8 & 1 & 1 & 1 & -1 & 1 & -1 & 5.08 & 629.73 \\
\hline 9 & -1 & -1 & -1 & 1 & -1 & 1 & 373.00 & 4696.29 \\
\hline 10 & 1 & -1 & -1 & 1 & 1 & 1 & 76.33 & 497.33 \\
\hline 11 & -1 & 1 & -1 & 1 & 1 & -1 & 2.91 & 582.00 \\
\hline 12 & 1 & 1 & -1 & 1 & -1 & -1 & 2.03 & 203.33 \\
\hline 13 & -1 & -1 & 1 & 1 & 1 & -1 & 2.54 & 100.36 \\
\hline 14 & 1 & -1 & 1 & 1 & -1 & -1 & 1.58 & 102.15 \\
\hline 15 & -1 & 1 & 1 & 1 & -1 & 1 & 75.80 & 334.75 \\
\hline 16 & 1 & 1 & 1 & 1 & 1 & 1 & 0.24 & 23.67 \\
\hline 17 & 0 & 0 & 0 & 0 & 0 & 0 & 9.91 & 154.40 \\
\hline 18 & 0 & 0 & 0 & 0 & 0 & 0 & 19.72 & 503.88 \\
\hline 19 & 0 & 0 & 0 & 0 & 0 & 0 & 7.23 & 196.27 \\
\hline \multicolumn{9}{|c|}{2} \\
\hline 0 & 0 & 0 & 0 & 0 & 0 & 0 & 14.62 & 224.99 \\
\hline \multirow{2}{*}{\multicolumn{6}{|c|}{ Factors }} & \multicolumn{3}{|c|}{ Real levels } \\
\hline & & & & & & -1 & 0 & +1 \\
\hline \multicolumn{6}{|c|}{$\mathrm{X}_{1}$ Yeast extract $(\mathrm{g} / \mathrm{L})$} & 0.0 & 1.0 & 2.0 \\
\hline \multicolumn{6}{|c|}{$X_{2}$ Urea $(\mathrm{g} / \mathrm{L})$} & 0.0 & 2.15 & 4.3 \\
\hline \multicolumn{6}{|c|}{$\mathrm{X}_{3}$ Ammonium sulfate $(\mathrm{g} / \mathrm{L})$} & 0.0 & 4.7 & 9.4 \\
\hline \multicolumn{6}{|c|}{$\mathrm{X}_{4}$ Sodium nitrate $(\mathrm{g} / \mathrm{L})$} & 0.0 & 6.0 & 12.0 \\
\hline \multicolumn{6}{|c|}{$\mathrm{X}_{5}$ Ammonium nitrate $(\mathrm{g} / \mathrm{L})$} & 0 & 2,85 & 5,7 \\
\hline \multicolumn{6}{|c|}{$\mathrm{X}_{6}$ Ammonium phosphate $(\mathrm{g} / \mathrm{L})$} & 0 & 3 & 6 \\
\hline
\end{tabular}


Table 3 Analysis of variance obtained for the $2^{6-2}$ fractional design with different $\mathrm{N}$ sources. Chicken fat was used as the carbon source at $30^{\circ} \mathrm{C}$ and $180 \mathrm{rpm}$

\begin{tabular}{llllll}
\hline Factor & Ss & Df & Ms & Fcalc & $p$-Value \\
\hline $\mathrm{X}_{1}$ & 6187.2 & 1 & 6187.19 & 1.297699 & 0.275190 \\
$X_{2}$ & 6645.6 & 1 & 6645.56 & 1.393840 & 0.258909 \\
$\mathrm{X}_{3}$ & 10588.1 & 1 & 10588.14 & 2.220754 & 0.160025 \\
$\mathrm{X}_{4}$ & 9762.0 & 1 & 9762.03 & 2.047487 & 0.176055 \\
$\mathrm{X}_{5}$ & 11039.8 & 1 & 11039.77 & 2.315481 & 0.152038 \\
$\mathrm{X}_{6}$ & 24057.5 & 1 & 24057.46 & 5.045808 & 0.042699 \\
Residue & 61981.5 & 13 & 4767.81 & & \\
Total & 130261.7 & 19 & & & \\
\hline
\end{tabular}

$S s$, sum of squares; $d f$, degrees of freedom; $M s$, mean square; $\mathrm{R}^{2}=0.5242$; $\mathrm{R}=0.7240 ; \mathrm{F}_{\text {tab }}(1 ; 13 ; 0.05)=4.67$

Thus, an empirical mathematical model for lipase is possible (Equation 1).

$Y(\mathrm{U} / \mathrm{mL})=236.21+57.78 .\left(\mathrm{X}_{1}\right)-55.61 .\left(\mathrm{X}_{1}\right)^{2}+152.40 .\left(\mathrm{X}_{2}\right)-4,70 .\left(\mathrm{X}_{2}\right)^{2}$

The 3-D response surface and contour plots obtained for the model are shown in Fig. 1a and b, respectively. As previously mentioned, when the concentrations of $\mathrm{N}$ source $\left(X_{2}\right)$ increased, the enzymatic activity also increased; thus, the highest lipase activities were obtained at the highest concentrations of $X_{2}$ (ammonium phosphate).

It is possible observe that this model is not conclusive, since the response surface does not have a region where the
Table 5 Analysis of variance obtained for the $2^{2} \mathrm{CCD}$ with chicken fat $\left(\mathrm{X}_{1}\right)$ and ammonium sulfate $\left(X_{2}\right)$

\begin{tabular}{llllll}
\hline Factor & Ss & df & Ms & Fcalc & $p$-Value \\
\hline $\mathrm{X}_{1}(\mathrm{~L})$ & 26635.6 & 1 & 26635.6 & 6.29071 & 0.046020 \\
$\mathrm{X}_{1}(\mathrm{Q})$ & 19634.1 & 1 & 19634.1 & 4.63711 & 0.074755 \\
$X_{2}(\mathrm{~L})$ & 185259.0 & 1 & 185259.0 & 43.75384 & 0.000575 \\
$X_{2}(\mathrm{Q})$ & 140.6 & 1 & 140.6 & 0.03321 & 0.861407 \\
$\mathrm{X}_{1} \times X_{2}$ & 671.5 & 1 & 671.5 & 0.15859 & 0.704239 \\
Residue & 25404.7 & 6 & 4234.1 & & \\
Total & 257863.4 & 11 & & & \\
\hline
\end{tabular}

Ss, sum of squares; df: degrees of freedom; $M s$, mean square; $\mathrm{R}^{2}=$ $0.9015 ; \mathrm{R}=0.9495 ; \mathrm{F}_{\text {tab }}(1 ; 6 ; 0.06)=5.99$

enzymatic activity is maximal but has a growing response. To variable $\mathrm{X}_{1}$ (chicken fat), it is possible to indicate the most suitable concentration to induce enzyme production $(12.5 \mathrm{~mL} /$ L). However, for the variable $X_{2}$, the results indicate that better production of the enzyme would occur at concentrations above $20 \mathrm{~g} / \mathrm{L}$. Since the concentration of $\mathrm{C}$ and N sources showed no interaction and the concentration of the most suitable carbon source was determined, then a univariate experiment was conducted to find the best concentration of ammonium phosphate.

Although the factorial design indicates that the lipase production would be favored by adding more than $20 \mathrm{~g} / \mathrm{L}$ of ammonium phosphate to the culture medium, in the univariate study there was no significant increase in activity between 15 and $25 \mathrm{~g} / \mathrm{L}$, including a marked decreased activity with $30 \mathrm{~g} / \mathrm{L}$

Table 4 CCD matrix (factorial $2^{2}$ ) containing four repetitions at the central point for the production of lipase by Burkholderia lata LBBIO-BL2 in SmF

\begin{tabular}{|c|c|c|c|c|c|}
\hline \multirow[t]{2}{*}{ Run } & \multicolumn{2}{|c|}{ Variables in coded levels } & \multicolumn{3}{|l|}{ Response } \\
\hline & $\mathrm{X}_{1}$ & $X_{2}$ & $Y(\mathrm{U} / \mathrm{mL})$ - Predicted & $Y(\mathrm{U} / \mathrm{mL})$-Observed & Specific activity (U/mg) \\
\hline 1 & -1 & -1 & 0.00 & 5.46 & 90.15 \\
\hline 2 & -1 & +1 & 257.54 & 297.00 & 1439.00 \\
\hline 3 & +1 & -1 & 68.31 & 42.96 & 196.03 \\
\hline 4 & +1 & +1 & 399.02 & 386.33 & 618.07 \\
\hline 5 & $-\alpha$ & 0 & 44.15 & 0.06 & 4.31 \\
\hline 6 & $+\alpha$ & 0 & 207.11 & 237.00 & 632.19 \\
\hline 7 & 0 & $-\alpha$ & 11.96 & 13.83 & 26.52 \\
\hline 8 & 0 & $+\alpha$ & 441.73 & 425.66 & 1781.97 \\
\hline 9 & 0 & 0 & 236.20 & 179.33 & 666.53 \\
\hline 10 & 0 & 0 & 236.20 & 169.00 & 908.93 \\
\hline 11 & 0 & 0 & 236.20 & 255.00 & 869.27 \\
\hline 12 & 0 & 0 & 236.20 & 341.67 & 1708.33 \\
\hline \multirow[t]{2}{*}{ Factors } & \multicolumn{5}{|c|}{ Actual levels } \\
\hline & $-\alpha$ & -1 & 0 & +1 & $+\alpha$ \\
\hline $\mathrm{X}_{1}($ Chicken fat, mL/L) & 0.00 & 0.35 & 1.25 & 2.15 & 2.50 \\
\hline$X_{2}($ Ammonium phosphate, $\mathrm{g} / \mathrm{L})$ & 0.00 & 1.75 & 6.00 & 10.15 & 12.00 \\
\hline
\end{tabular}

$\alpha=1.41$ 

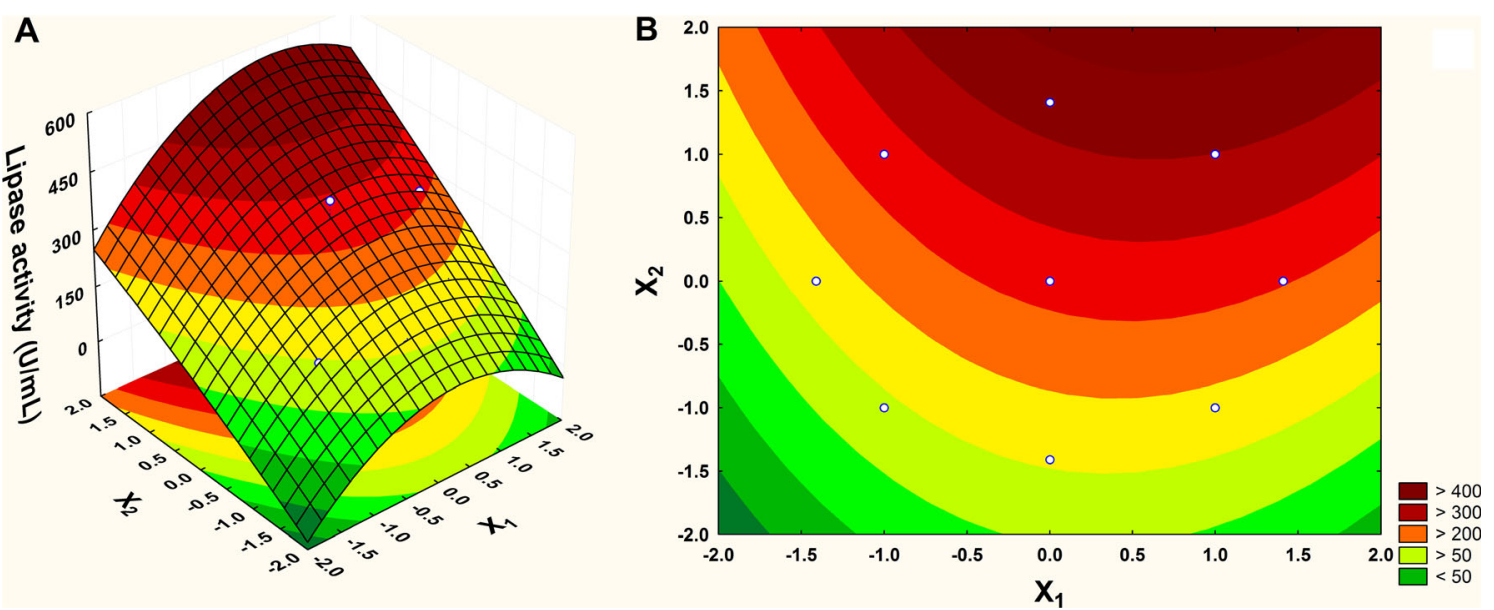

Fig. 1 Three-dimensional response surface (a) and contour (b) plots of lipase activity $(\mathrm{U} / \mathrm{mL})$ obtained by submerged fermentation of Burkholderia lata LBBIO-BL2 on medium with various concentrations of chicken fat $\left(\mathrm{X}_{1}\right)$ and ammonium phosphate $\left(X_{2}\right)$

of salt. Increasing the $\mathrm{N}$ source up to $15 \mathrm{~g} / \mathrm{L}$, the lipase production was maximum $(183.77 \mathrm{U} / \mathrm{mL}$ and 1647.26 $\mathrm{U} / \mathrm{mg}$ ) (Fig. 2).

\section{Effect of the initial $\mathrm{pH}$ and the temperature on lipase production}

To evaluate the effect of the initial $\mathrm{pH}$ of the culture medium and the incubation temperature on lipase production by $B$. lata, fermentation was carried out at $12.5 \mathrm{~mL} / \mathrm{L}$ of chicken fat and $15 \mathrm{~g} / \mathrm{L}$ of ammonium phosphate. The enzymatic activity was followed specially in two different conditions: $\mathrm{pH} 8$ and $37^{\circ} \mathrm{C}$ (standard conditions in fermentation experiments) and $\mathrm{pH} 7$ and $55^{\circ} \mathrm{C}$ (a condition established after the characterization of the enzyme, described below).

The initial culture $\mathrm{pH}$ had prominent effects on the lipase production by $B$. lata. Initial $\mathrm{pH}$ of culture medium ranging from 7 to 9 promoted good lipase production with the initial $\mathrm{pH}$ of 8 showing the best lipase activity (Fig. 3). In contrast, $\mathrm{pH}$ below 6 and above 9 on the $\mathrm{pH}$ of the initial culture has drastic negative effects.

The effect of initial $\mathrm{pH}$ of the culture medium is directly related to the microorganism's growth. The highest enzyme activity was obtained exactly in fermentations where higher cell growth occurred. As a consequence of cell growth, beside enzymatic activity, acidification of the medium was also seen in all experiments. Cultures started at $\mathrm{pH} 7$ had a final $\mathrm{pH}$ of 5.06, while the $\mathrm{pH}$ experiments initiated in 8 and 9, finished with a $\mathrm{pH}$ around 6.5 . It is interesting to notice how small differences in $\mathrm{pH}$ can also provide important effects on the metabolism of the microorganism. Comparing the cultures at $\mathrm{pH} 6$ and the control (without correction, $\mathrm{pH}$ 6.43), there was double the activity in the control flask and lower acidification after $72 \mathrm{~h}$ of cultivation (pH 5.26 and 3.6 in the control flasks and adjusted at $\mathrm{pH} 6$, respectively), although approximately with the same cell growth.
At a different temperature fermentation, considering the incubation time of $72 \mathrm{~h}$, it was observed that the culture temperature had an effect on the lipase production, with increased activity between 30 and $35^{\circ} \mathrm{C}$ (Table 6). However, the experiment was also accompanied with $48 \mathrm{~h}$ of culture, and in this period it is evident the highest activity was at $35^{\circ} \mathrm{C}$. The cell growth did not change between 48 and $72 \mathrm{~h}$, suggesting that even at $48 \mathrm{~h}$, the bacteria was already in the stationary phase of cell growth. Thus, the different activities obtained are probably due to metabolic changes caused by temperature.

\section{Kinetic characterization}

For kinetic characterization studies, the lipase was produced in basal culture media containing chicken fat $(12.5 \mathrm{~mL} / \mathrm{L})$ and ammonium phosphate $(15 \mathrm{~g} / \mathrm{L})$ at $30^{\circ} \mathrm{C}, 180 \mathrm{rpm}, \mathrm{pH} 6.6$ for $72 \mathrm{~h}$ resulting in an enzyme extract, $250 \mathrm{U} / \mathrm{mL}$ (standard method assay).

The effect of temperature on the enzyme activity in a range between 20 and $90{ }^{\circ} \mathrm{C}$ was evaluated (Fig. $4 \mathrm{~b}$ ). The highest activities were observed in the range of $55^{\circ} \mathrm{C}(542.76 \mathrm{U} / \mathrm{mL})$ at $65{ }^{\circ} \mathrm{C}(510.26 \mathrm{U} / \mathrm{mL})$, but considerable activity was also observed at high temperatures with $138.92 \mathrm{U} / \mathrm{mL}$ at $85{ }^{\circ} \mathrm{C}$ $\left(25.60 \%\right.$ of the activity measured at $\left.55^{\circ} \mathrm{C}\right)$.

To determine the thermal stability of $B$. lata lipase, the enzyme extract was incubated at temperatures between 20 and $70{ }^{\circ} \mathrm{C}$ (Fig. 4a). It was observed that $B$. lata lipase, even after $60 \mathrm{~min}$ of incubation at 50 and $60{ }^{\circ} \mathrm{C}$, held 93.3 and $85.4 \%$ of the initial activity. However, when the temperature increased to $70{ }^{\circ} \mathrm{C}$, there was total loss of enzyme stability.

The effect of $\mathrm{pH}$ on $B$. lata lipase was investigated at $\mathrm{pH}$ values between 2.2 and 10. Higher activities were observed in the $\mathrm{pH}$ range between 4.0 and 9.0, with maximum activity at $\mathrm{pH}$ 7.0. Reasonable activities were obtained even at more 
Fig. 2 Influence of ammonium phosphate concentration as the $\mathrm{N}$ source on the production of lipase by Burkholderia lata in SmF. Culture conditions: $12.5 \mathrm{~mL} / \mathrm{L}$ of chicken fat; $180 \mathrm{rpm}, 30^{\circ} \mathrm{C}, 72 \mathrm{~h}$

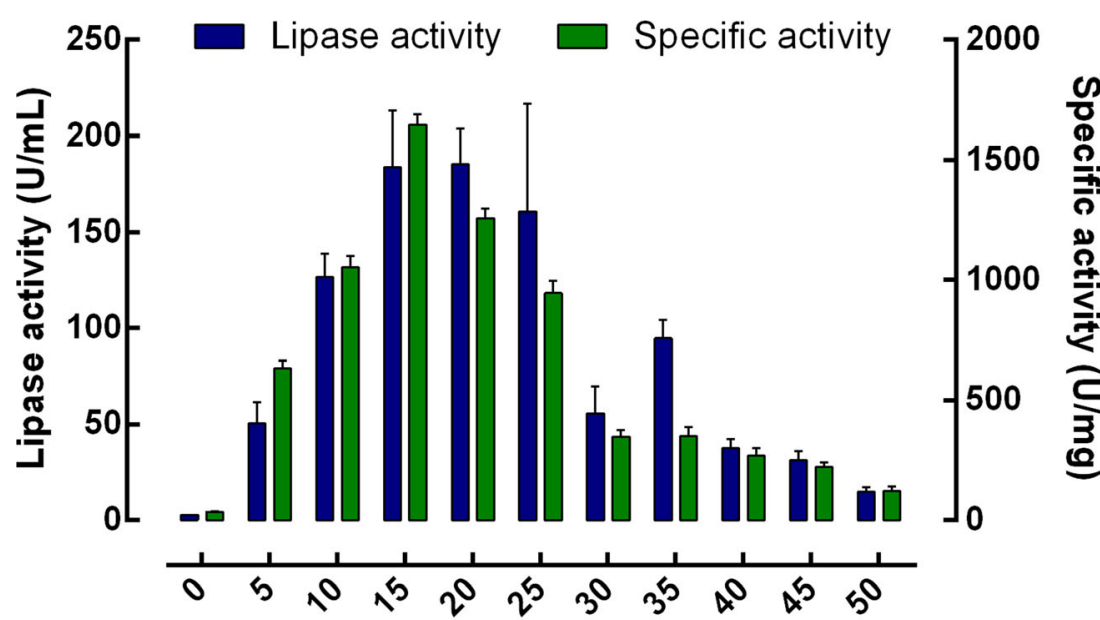

Ammonium phosphate (g/L) acidic $\mathrm{pH}$ values, at $\mathrm{pH} 3.0$ and 4.0 we observed 65.14 and $89.56 \%$ of relative activity, respectively (Fig. $4 \mathrm{~d}$ ).

The stability of the enzymatic activity of $B$. lata lipase at different $\mathrm{pH}$ values was investigated. The enzyme was stable at $\mathrm{pH}$ values between 3.0 and 10.0, after incubation for $1 \mathrm{~h}$ at $25{ }^{\circ} \mathrm{C}$ (Fig. 4c). Even at pH 2.2, the enzyme showed $78.20 \%$ residual activity. When in contact with the phosphate-citrate buffer $\mathrm{pH} 3.5$ to 6.0 and $\mathrm{KH}_{2} \mathrm{PO}_{4}-\mathrm{NaOH}$ buffer $\mathrm{pH} 6.0$ and 8.0 , there was an activation of the lipase in relation to the activity of the enzyme not incubated. This effect has been reported for other lipases, but no mechanism has been proposed to explain this phenomenon.

\section{Activity on different substrates}

The $B$. lata lipase showed high hydrolysis activity against triacylglycerol of different chain sizes, synthetic and natural (Table 7). The triolein is the typical substrate for lipases, and it is not hydrolyzed by esterases, thus, the ability to hydrolyze this triacylglycerols indicates the presence of true lipases in the enzyme extract. This definition applies even when considering that the rate of hydrolysis of triolein was lower than that of other short chain triglycerides such as tributyrin (4:0).

Using different natural substrates, the $B$. lata lipase shows the most hydrolysis activity on linseed and soy oils, and chicken fat for which the predominant fatty acids are linolenic, linoleic, and oleic acid, respectively, as already shown in Table 1. Despite variations in degree of saturation in the fatty acids, they have the same size chain (18 carbons).

Lipase immobilization by adsorption on Celite ${ }^{\circledR} 545$

After characterization of the enzyme, the crude extract was used in adsorption tests with immobilization on Celite $^{\circledR}$ 545. This support consists mainly of silica $\mathrm{SiO}_{2}(91.5 \%)$ with an average particle size of $0.002 \mathrm{~mm}^{2}$ (range $0.02-0.1 \mathrm{~mm}$ ) measured in our
Fig. 3 Lipase production by B. lata and cell growth in culture medium with different initial $\mathrm{pHs}$ The initial $l n$ cell number added to fermentation was 18 . Culture medium contained $1.25 \mathrm{~mL} / \mathrm{L}$ of chicken fat and $15 \mathrm{~g} / \mathrm{L}$ of ammonium phosphate. Control fermentation without $\mathrm{pH}$ adjustment was at $\mathrm{pH}$ 6.4. Culture conditions: $180 \mathrm{rpm}, 30^{\circ} \mathrm{C}$ and $72 \mathrm{~h}$. Test conditions: citratephosphate buffer $0.05 \mathrm{~mol} / \mathrm{L}$ $\mathrm{pH} 7.0,55^{\circ} \mathrm{C}$. Assays carried out in triplicate

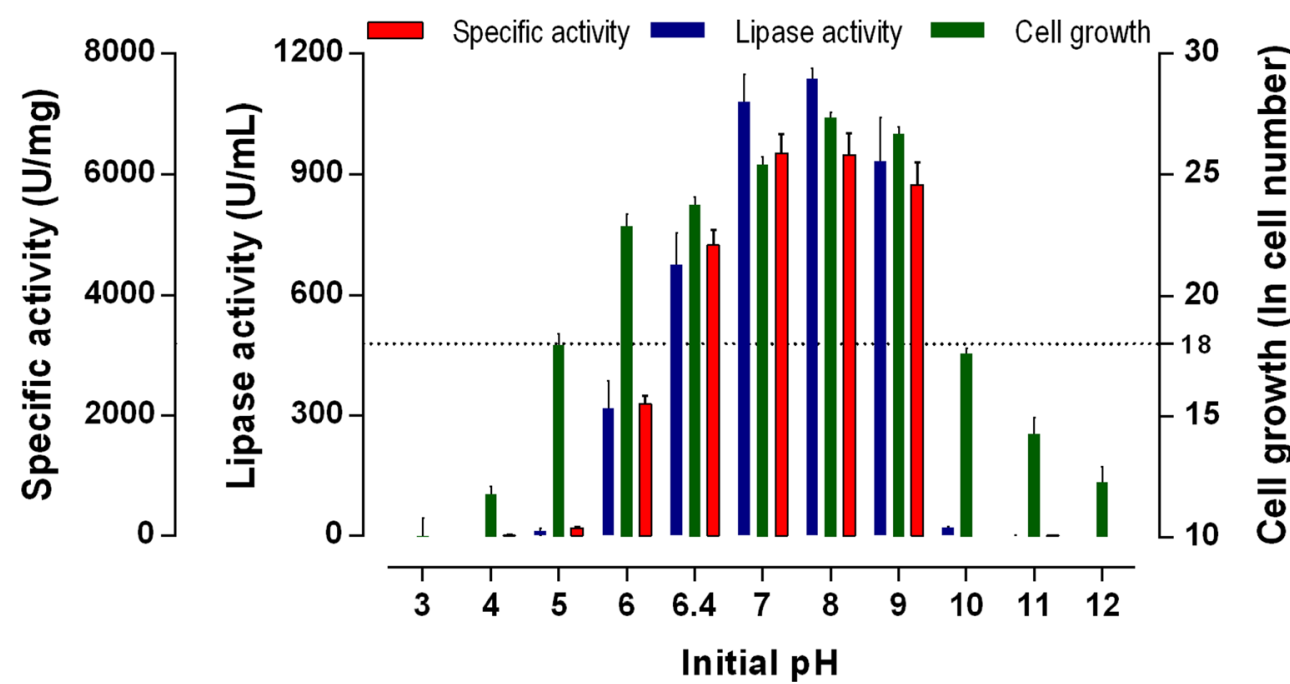


Table 6 Lipase production by B. lata and cell growth in fermentations performed at different temperatures

\begin{tabular}{lllll}
\hline Time $(\mathrm{h})$ & Temperature $\left({ }^{\circ} \mathrm{C}\right)$ & Activity $\left(\mathrm{U} / \mathrm{mL} ; \mathrm{pH} 7 ; 55^{\circ} \mathrm{C}\right)$ & Activity $\left(\mathrm{U} / \mathrm{mL} ; \mathrm{pH} 8 ; 37^{\circ} \mathrm{C}\right)$ & Cell growth $(\ln )$ \\
\hline 48 & 30 & $630.38 \pm 37.72$ & $192.77 \pm 14.62$ & 24.73 \\
& 35 & $1124.91 \pm 128.23$ & $359.11 \pm 32.26$ & 26.13 \\
& 40 & $471.94 \pm 178.03$ & $240.74 \pm 4.85$ & 8.87 \\
72 & 45 & $0.00 \pm 0.00$ & $0.00 \pm 0.00$ & 25.43 \\
& 30 & $1137.83 \pm 25.15$ & $323.65 \pm 17.27$ & 26.41 \\
& 35 & $997.81 \pm 96.01$ & $319.11 \pm \pm 57.56$ & 26.07 \\
& 40 & $587.90 \pm 24.01$ & $171.56 \pm 34.69$ & 0.00
\end{tabular}

The initial $\mathrm{ln}$ cell number added to fermentation was 18 . Culture medium containing $1.25 \mathrm{~mL} / \mathrm{L}$ of chicken fat and $15 \mathrm{~g} / \mathrm{L}$ of ammonium phosphate. Culture conditions: $180 \mathrm{rpm}, \mathrm{pH} 8.00$

laboratory. Celite also shows a permeability of 4.8 Darcies, a pore size of 17 microns and a superficial area of $2.19 \mathrm{~m}^{2} / \mathrm{g}$ (manufacturer's data).
For immobilization tests we used enzyme extract with an activity of $135.45 \mathrm{U} / \mathrm{mL}$. To $5 \mathrm{~g}$ of the support was added an equivalent to $1354.50 \mathrm{U}$ of enzyme activity. After
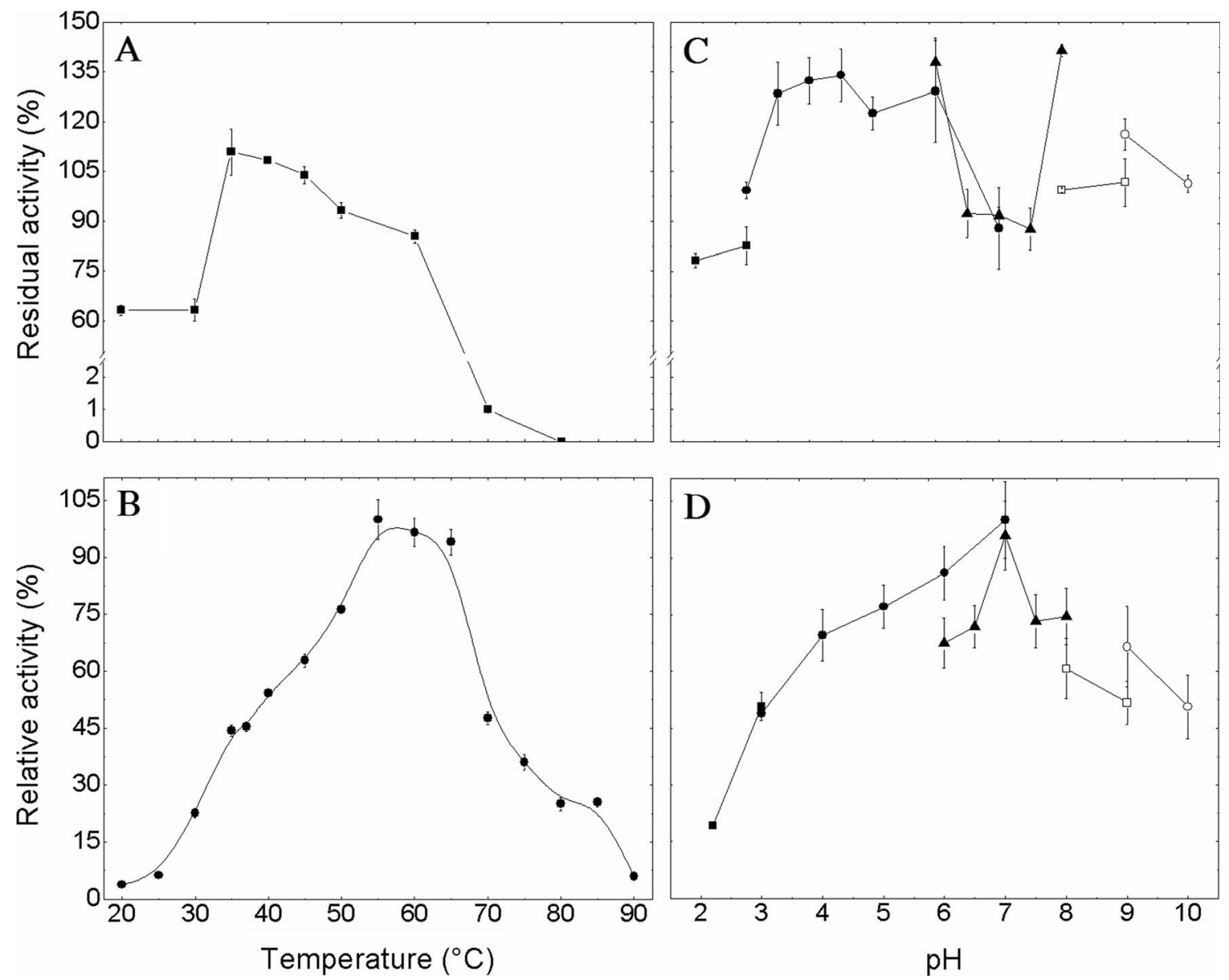

Fig. 4 Effect of temperature on the stability (a) and activity (b) of B. lata lipase. Test conditions: temperature between 20 and $90{ }^{\circ} \mathrm{C}$, phosphate buffer $0.05 \mathrm{~mol} / \mathrm{L} \mathrm{pH} \mathrm{8.0.} \mathrm{Assays} \mathrm{were} \mathrm{carried} \mathrm{out} \mathrm{in} \mathrm{triplicate.} \mathrm{All}$ activities was calculated relative to the activity measured at the standard temperature of $55^{\circ} \mathrm{C}(542.76 \mathrm{U} / \mathrm{mL}, 100 \%)$. Effect of $\mathrm{pH}$ on the stability (C) and activity (D) of B. lata lipase at different pHs. Test conditions: $37^{\circ} \mathrm{C}$. Residual activity in the stability tests after $1 \mathrm{~h}$ of incubation at

$25^{\circ} \mathrm{C}$. Buffers used in the two assays $(0.05 \mathrm{~mol} / \mathrm{L})$ : Glycine- $\mathrm{HCl} \mathrm{pH} 2.2$ to $3.0(\mathbf{\bullet})$, citrate-phosphate $\mathrm{pH} 3.0$ to $7,0(\bullet), \mathrm{KH}_{2} \mathrm{PO}_{4}-\mathrm{NaOH}$ pH 6.0 to $8.0(\boldsymbol{\Delta})$, Tris- $-\mathrm{HCl}$ pH 8.0 and $9.0(\square)$ and Glycine- $\mathrm{NaOH}$ pH 9 and 10 (०). The activities were compared with the activity determined in phosphate buffer $0.05 \mathrm{~mol} / \mathrm{L}$ pH 8.0 without prior incubation $(100 \%, 250$ $\mathrm{U} / \mathrm{mL}$ ). Assays carried out in triplicate 
Table 7 Burkholderia lata lipase activity on different substrates

\begin{tabular}{ll}
\hline Substrate & Lipase activity $(\mathrm{U} / \mathrm{mL})$ \\
\hline$p$-Nitrophenyl palmitate $(p \mathrm{NPP}, 16: 0)$ & $445.18 \pm 13.5$ \\
Triolein $\left({ }^{\Delta 9} 18: 1\right)$ & $405.06 \pm 11.3$ \\
Tributyrin (4:0) & $581.46 \pm 5.7$ \\
Linseed oil & $470.19 \pm 26.1$ \\
Chicken fat & $378.92 \pm 15.0$ \\
Soybean oil & $346.26 \pm 20.4$ \\
Corn oil & $195.99 \pm 25.9$ \\
Olive oil & $120.85 \pm 31.5$ \\
Crambe oil & $117.59 \pm 25.9$ \\
\hline
\end{tabular}

Test conditions: $55^{\circ} \mathrm{C}, \mathrm{pH}$ 7.0. determinations in triplicates

immobilization, we obtained the activity of the immobilized enzyme with $1041.47 \mathrm{U} / \mathrm{g}$ support, with an exceptional yield of $768.89 \%$, superior to those found in the literature (Chang et al. 2007).

The immobilized enzyme, the Celite, and the free lipase were analyzed by FT-IR to ascertain the nature of the enzyme/carrier interaction. The spectra of immobilized enzyme showed amide bands typical of lipases, but with less noise than free lipase, which can be explained by a possible selective attachment of the protein to the solid support providing a crude purification. The band at $1088 \mathrm{~cm}^{-1}$ (siloxane group $\mathrm{Si}-\mathrm{O}-\mathrm{Si}-)$ of the support remains predominant. No additional band in the spectrum for the immobilized derivative was observed indicating that no covalent bond was between the enzyme and support, but that there was physical adsorption.

The lipolytic activity of the immobilized enzyme using $p$ NPP as substrate was followed by five subsequent cycles with washing the support with isopropanol between cycles. In this aqueous reaction environment, rapid desorption of the enzyme was observed. Decreases were observed in the activity of $34.5,64.2,84.3$, and $95.4 \%$ between the second and fifth recycles.

However, for the enzyme application of the catalysis, the reaction medium is generally composed of organic solvents. We lack additional evaluation of free and immobilized enzyme stability in this environment. Here can be observed great stability for both polar and nonpolar solvents. For the nonpolar, there is emphasis on the n-hexane (Table 8). For free enzyme better results were obtained in $50 \%$ ethanol, $\mathrm{n}$-hexane, and heptane with residual activities of $178.38,256.96$, and $261.54 \%$, respectively. For the immobilized enzyme, n-hexane showed the highest activity when compared to the initial $(115.40 \%)$.

\section{Discussion}

Most lipases are inducible enzymes and addition of oleic, linoleic, and linolenic acids proved to enhance lipase production. Natural substrates of lipase are triglycerides of long chains, so triolein is used in most cases as a standard substrate (Gupta et al. 2004). The selection of a carbon source that is also an inducer of enzyme production for the content of longchain fatty acids, but has also affordable cost, is one of the most common concerns in studies of lipase production by microorganisms.

In this sense, the results presented here have great interest for enzyme industries. In cultures of B. lata LBBIO-BL02 in this work there was obtained high activity in comparison with the literature, using as a carbon source chicken fat from disposals of the poultry industry. Although of an animal source, chicken fat has a high content of unsaturated long chain fatty acids ( $>57 \%), 43 \%$ of it is oleic acid; justifying it as good source for lipase production, as observed in other studies conducted by our group for lipase production by Fusarium sp (GFC) (Oliveira and Lima 2014). Besides our work there is no report in the literature of lipase production using chicken oil. Olive oil is currently used as an inducer of lipases (Boekema et al. 2007); however, this increases the production cost by seven times compared to chicken fat.

Chicken fat is a disposal of the poultry industry together with the viscera, feathers, and blood (Arnaud et al. 2004), contributing to the increase of waste released in nature. Use of this fatty material for enzyme production of high added value appears as an excellent alternative for the industry, with great appeal related to the preservation of the environment.

Apart from chicken fat, the present production cost/lipase production rate is quite competitive the crambe and palm oils. The crambe (Crambe abyssinica) is a non-food oilseed, its oil is toxic for human or animal consumption and has exclusively industrial application. The $B$. lata lipase production in the EU, where the culture is already deployed, can be favorable.

Palm oil is extracted from palm (Elaeais guineensis), cultivated in the Brazilian northeast and the western coast of Africa. It has a food use, but is limited to local customs. Considering that the oil is extracted in poor regions, their use for lipase production could represent, in addition to economic viability for the bioprocess, increased income for the population.

Besides being a carbon source, the type of $\mathrm{N}$ source in the medium has great influence in lipase production by microorganisms. Generally, organic N is preferred, such as tryptone, peptone, and yeast extract (Gupta et al. 2004), which have been used as a nitrogen source for lipase production by various Burkholderia sp. (Dalal et al. 2008; Lau et al. 2011; Lo et al. 2012). The cost of those sources is high compared to that of inorganic N salts (Oliveira et al. 2013), and its presence hinders subsequent stages of protein purification. 
Table 8 Study of stability Burkholderia lata LBBIO-BL02 lipase from different organic solvents and concentrations

\begin{tabular}{|c|c|c|c|c|}
\hline & $\log P$ & Concentration $(\%)$ & $\begin{array}{l}\text { Free enzyme } \\
\text { Residual activity (\%) }\end{array}$ & $\begin{array}{l}\text { Immobilized enzyme } \\
\text { Residual activity (\%) }\end{array}$ \\
\hline Control & & & $100.0 \pm 8.2$ & $100.0 \pm 2.5$ \\
\hline \multirow[t]{4}{*}{ Methanol } & \multirow[t]{4}{*}{-0.73} & 25 & $86.5 \pm 21.5$ & $33.0 \pm 5.3$ \\
\hline & & 50 & $119.7 \pm 5.3$ & $28.2 \pm 4.6$ \\
\hline & & 75 & $50.7 \pm 6.4$ & $22.8 \pm 5.8$ \\
\hline & & 100 & $0.0 \pm 0.0$ & $36.9 \pm 3.0$ \\
\hline \multirow[t]{4}{*}{ Ethanol } & \multirow[t]{4}{*}{-0.24} & 25 & $105.2 \pm 12.8$ & $37.7 \pm 3.1$ \\
\hline & & 50 & $178.4 \pm 7.8$ & $16.7 \pm 7.0$ \\
\hline & & 75 & $98.8 \pm 8.6$ & $19.5 \pm 6.3$ \\
\hline & & 100 & $28.2 \pm 8.4$ & $48.5 \pm 10.9$ \\
\hline \multirow[t]{4}{*}{ Iso-propanol } & \multirow[t]{4}{*}{-0.28} & 25 & $162.7 \pm 7.2$ & $21.7 \pm 0.6$ \\
\hline & & 50 & $82.4 \pm 39.5$ & $19.9 \pm 0.6$ \\
\hline & & 75 & $91.5 \pm 12.0$ & $17.0 \pm 0.5$ \\
\hline & & 100 & $72.0 \pm 7.9$ & $10.3 \pm 0.6$ \\
\hline \multirow[t]{4}{*}{ Acetone } & \multirow[t]{4}{*}{-0.23} & 25 & $72.5 \pm 9.8$ & $36.7 \pm 3.0$ \\
\hline & & 50 & $70.5 \pm 5.7$ & $31.4 \pm 0.7$ \\
\hline & & 75 & $61.0 \pm 3.2$ & $26.8 \pm 3.1$ \\
\hline & & 100 & $72.3 \pm 4.2$ & $33.1 \pm 1.8$ \\
\hline Butanol & 0.8 & 100 & $6.1 \pm 3.3$ & $21.4 \pm 2.5$ \\
\hline Iso-amyl & 1.42 & 100 & $41.0 \pm 0.0$ & $28.4 \pm 0.9$ \\
\hline Octanol & 2.8 & 100 & $41.4 \pm 11.2$ & $21.3 \pm 2.4$ \\
\hline Toluene & 2.5 & 100 & $115.7 \pm 45.7$ & $42.1 \pm 2.2$ \\
\hline Hexane & 3.5 & 100 & $257.0 \pm 5.4$ & $115.4 \pm 3.0$ \\
\hline Heptane & 4 & 100 & $261.5 \pm 8.2$ & $59.5 \pm 6.0$ \\
\hline Octane & 4.51 & 100 & $44.5 \pm 1.6$ & $65.6 \pm 4.9$ \\
\hline
\end{tabular}

${ }^{\mathrm{a}}$ The percentages values accompanying polar organic solvents correspond to the amount of solvent in phosphate buffer $0.05 \mathrm{~mol} / \mathrm{L} \mathrm{pH} 8.0$. Tests in triplicate. Log P: Solvent hydrophobicity measurement computed by the logarithm of partition coefficient of a given solvent in a octanol/water system standard. Hydrophilic solvents: $-2.5<\log \mathrm{P}<0$

In this work the best $\mathrm{N}$ source was an inorganic salt (ammonium phosphate).Reports in the literature show that the lipase production could be improved by inorganic nitrogen sources while the cell growth was influenced by organic ones (Liu et al. 2012). The results indicated that the expensive organic $\mathrm{N}$ sources can be replaced by lower cost inorganic $\mathrm{N}$ salts with a gain of lipase activity. They are significant, considering the cost advantage and the ease of enzyme purification. Rathi et al. (2001) reported that ammonium phosphate did not affect the lipase production by a $B$. cepacia strain significantly; however, higher specific activity was observed.

The best $\mathrm{pH}$ of a culture medium to have the maximum lipase production by Burkholderia isolates is reported to be around 7-9. Rathi et al. (2001) reported the B. cepacia preferred $\mathrm{pH}$ around 7.0 and 9.0, respectively, for optimal growth and lipase production, Lau et al. (2011) found the best $\mathrm{pH}$ for lipase production by $B$. cenocepacia ST8 was 9.0. Others microorganism, such as Bacillus coagulans BTS-3 (Kumar et al. 2005) and Pseudomonas sp. MSI057 (Kiran et al. 2008) showed the best lipase production at $\mathrm{pH} 8.5$ and 9.0, respectively. Hence, initial culture $\mathrm{pH}$ is an important factor which affects the lipase production, and it varies with the types of microorganisms.

The $B$. lata LBBIO-BL02 lipase activity and stability in the range of temperature of 37 to $65^{\circ} \mathrm{C}$ may make it interesting for use in biocatalysis, as these characteristics are not common to lipases from mesophilic bacterial strains such as $B$. lata. Even after $1 \mathrm{~h}$ incubation at $\mathrm{pH}$ extreme acid 2.2 and alkaline10.0, B. lata lipase remained active showing residual activity of 78.20 and 101.36 , respectively. The activity and stability shown by the $B$. lata lipase at acid $\mathrm{pH}$ are not common among lipases produced by bacteria, which are generally more stable and active at neutral or alkaline $\mathrm{pH}$ values.

Wang et al. (2009), studying B. cepacia lipase, reported maximum activity of the enzyme on $p$ NPP at $30{ }^{\circ} \mathrm{C}$ and $\mathrm{pH} 9.0$, while keeping only $44 \%$ residual activity after $60 \mathrm{~min}$ at $50{ }^{\circ} \mathrm{C}$, has activity decrease of $50 \%$ at $\mathrm{pH} 5$. To the other hand, Park et al. (2007) reported that lipase from Burkholderia sp. HY-10 exhibited the highest $p$ NPP hydrolysis at $60^{\circ} \mathrm{C}$ and $\mathrm{pH} 8.5$, but low stability at higher temperature 
$\left(25 \%\right.$ at $60{ }^{\circ} \mathrm{C}$ ). Yang et al. (2007), using a titrimetric assay, found the optimal temperature for B. cepacia $\mathrm{G} 63$ at $70{ }^{\circ} \mathrm{C}$ and $\mathrm{pH} 8.0$, and kept stable at a temperature range of 40 $70{ }^{\circ} \mathrm{C}$. Liu et al. (2006) reported that the optimal reaction conditions of lipase from Burkholderia sp. C20 were pH 9.0 and $55^{\circ} \mathrm{C}$ (titrimetric assay).

The results of activity and stability in a wide $\mathrm{pH}$ range (3.0 to 10.0 ), are also desirable in catalysis and are added to the good characteristics in terms of temperature by the $B$. lata lipase.

After $\mathrm{pH}$ and composition of the fermentation media studies, the enzymatic activity of the fermentation broth was $1137.82 \mathrm{U} / \mathrm{mL}$ with $0.53 \mathrm{mg} / \mathrm{mL}$ of protein, resulting in a specific activity of $2146.83 \mathrm{U} / \mathrm{mg}$. In the literature, strains of Burkholderia cepacia (Rathi et al. 2001), Burkholderia cepacia ATCC 25609, Burkholderia multivorans V2 (Dandavate et al. 2009), and other lipase-producing bacteria, such as Pseudomonas aeruginosa (Joshi and Khare 2013) and Bacillus sphaericus MTCC 7526 (Joseph and Ramteke 2012), produced, on average, 2 to $4 \mathrm{mg}$ of protein per $\mathrm{mL}$ of fermentation extract, resulting in a specific activity of 51.0, 0.23, $1.76,0.28$, and $182.8 \mathrm{U} / \mathrm{mg}$, respectively.

The overproduction of lipase by Yarrowia lipolytica have been well-studied during the last 10-15 years. The optimization of conditions for overproduction of lipase was done (Fickers et al. 2011). Pignède et al. (2000) using a genetically modified $Y$. lipolytica was able to produce $0.2 \mathrm{U} / \mathrm{mL}$ (titrimetric assay using olive oil). Our B.lata LBBIOBL02 strain, using the same assay method was able to show activity of $120 \mathrm{U} / \mathrm{mL}$. That demonstrated the advantage of $B$. lata LBBIO-BL02 wild strain in comparison to a traditional yeast producer.

Thus, the B. lata strain studied shows lipase production with higher volumetric and specific activity than reported in the literature for both synthetic substrates ( $p$ NPP), triolein, and natural oils, justifying the interest in this enzyme study.

The $B$. lata lipase was easily immobilized on Celite. Celite (diatomaceous earth) is one of the most popular carriers in immobilization of lipases due, mostly, for its affordable price, and it can be utilized both in adsorption and covalent attachment. Celite is hydrophilic, and its structure and properties can vary significantly as a function of production process. Several Celite types are commercially available, and the pore size of Celite can vary from $\mu \mathrm{m}$ to $\mathrm{mm}$, and the shape of the particles can be rods or beads. The shape and porosity greatly affects the adsorption of enzymes as well as the ability to retain water inside the pores. Many commercial lipase preparations are based on Celite powder, e.g., Amano lipase PS-D from Burkholderia cepacia (Hara 2011).

With $B$. lata immobilized lipase, it was possible to use it for up to three cycles of hydrolysis while maintaining $35 \%$ of the initial activity $(1041.47 \mathrm{U} / \mathrm{g})$. In cases of immobilization on Celite, the yields of hydrolysis recycles cited in the literature are low, with a loss of up to $70 \%$ in the first recycle, due to the existing weak hydrophobic interaction between the enzyme/support on the adsorption (Chang et al. 2007). The desorption may be increased in the presence of a surfactant (Triton $\mathrm{X}-100)$ normally used in the preparation of emulsified substrates.

The use of lipases in biocatalysis, however, occurs especially in organic solvent medium due to the high solubility of the substrates and products, to hydrolytic reverse reaction, and modification of the enzyme specificity. In principle, the ability to catalyze reactions in organic solvent medium was been mainly described as characteristic of lipases (Jaeger et al. 1994). Furthermore, the enzyme activity in these systems is typically much smaller than in aqueous solutions (Pencreac'h and Baratti 2001). In an apparent paradox, the stability of the protein is lower in water miscible solvents $(-2.5<\log \mathrm{P}<0)$ than in hydrophobic solvents $(\log \mathrm{P}>0)$. The poor stability in hydrophilic solvents represent an issue for the use of lipases involving, for example, the esterification of sugars in the production of biosurfactants, since these reactions consists of polar solvents such as 2-methyl-2-butanol (Soultani et al. 2001). Accordingly, the B. lata lipase presents unusual and very desirable characteristics, since its stability remained above $50 \%$ for all miscible solvents in concentrations of up to $75 \%$. These results are similar to those obtained for Burkholderia cepacia G63, confirming the high stability in water miscible organic solvents of lipases produced by the Burkholderia genus (Yang et al. 2007).

\section{Conclusion}

The findings of this work demonstrated overproducing lipase by a wild strain of Burkholderia lata LBBIOBL02. The bacterial isolate was found to be a producer of lipase with market potential, with high lipase activity obtained on a low cost nutrient medium. The lipase activity obtained was $1137.82 \mathrm{U} / \mathrm{mL}$ and $2146.83 \mathrm{U} / \mathrm{mg}$ with desirable characteristics. Moreover, the use of chicken fat as an inducer for lipase production appears as an excellent alternative, with great appeal related to the environment. Lipase was successfully immobilized on Celite by adsorption and showed a promising future as it allows easy immobilization with a simple and inexpensive process.

Acknowledgments B.H. Oliveira is grateful to $\mathrm{CNPq}$ for a $\mathrm{PhD}$ scholarship. 


\section{References}

Arnaud E, Relkin P, Pina M, Collignan A (2004) Characterisation of chicken fat dry fractionation at the pilot scale. Eur J Lipid Sci Technol 106:591-598. doi:10.1002/ejlt.200400946

Boekema BKHL, Beselin A, Breuer M, Hauer B, Koster M, Rosenau F, Jaeger KE, Tommassen J (2007) Hexadecane and tween 80 stimulate lipase production in Burkholderia glumae by different mechanisms. Appl Environ Microbiol 73:3838-44. doi:10.1128/AEM. 00097-07

Bradford MM (1976) A rapid and sensitive method for the quantitation of microgram quantities of protein utilizing the principle of protein-dye binding. Anal Biochem 72:248-54

Chang S-FS-W, Yen Y-H, Shieh C-J (2007) Optimum immobilization of Candida rugosa lipase on Celite by RSM. Appl Clay Sci 37:67-73. doi:10.1016/j.clay.2006.12.001

Dalal S, Singh PK, Raghava S, Rawat S, Gupta MN (2008) Purification and properties of the alkaline lipase from Burkholderia cepacia A.T.C.C. 25609. Biotechnol Appl Biochem 51:23-31. doi:10. 1042/BA20070186

Dandavate V, Jinjala J, Keharia H, Madamwar D (2009) Bioresource Technology Production, partial purification and characterization of organic solvent tolerant lipase from Burkholderia multivorans V2 and its application for ester synthesis. Bioresour Technol 100:3374 3381. doi:10.1016/j.biortech.2009.02.011

Fickers P, Marty A, Nicaud JM (2011) The lipases from Yarrowia lipolytica: genetics, production, regulation, biochemical characterization and biotechnological applications. Biotechnol Adv 29:63244. doi:10.1016/j.biotechadv.2011.04.005

Gupta R, Gupta N, Rathi P (2004) Bacterial lipases: an overview of production, purification and biochemical properties. Appl Microbiol Biotechnol 64:763-81. doi:10.1007/s00253-004-1568-8

Hara P (2011) Immobilization of Burkholderia cepacia lipase: kinetic resolution in organic solvents, ionic liquids and in their mixtures. Dissertation, Uiversity of Turku, Turku, Finland.

Jaeger KE, Ransac S, Dijkstra BW, Colson C, van Heuvel M, Misset O (1994) Bacterial lipases. FEMS Microbiol Rev 15:29-63. doi:10. 1111/j.1574-6976.1994.tb00121.x

Joseph B, Ramteke PW (2012) Extracellular solvent stable cold-active lipase from psychrotrophic Bacillus sphaericus MTCC 7526: partial purification and characterization. Ann Microbiol 63:363-370. doi: 10.1007/s13213-012-0483-y

Joshi C, Khare SK (2013) Purification and characterization of Pseudomonas aeruginosa lipase produced by SSF of deoiled Jatropha seed cake. Biocatal Agric Biotechnol 2:32-37. doi:10. 1016/j.bcab.2012.08.006

Kawakami K, Oda Y, Takahashi R (2011) Application of a Burkholderia cepacia lipase-immobilized silica monolith to batch and continuous biodiesel production with a stoichiometric mixture of methanol and crude Jatropha oil. Biotechnol Biofuels 4:42. doi:10.1186/1754$6834-4-42$

Kiran GS, Shanmughapriya S, Jayalakshmi J, Selvin J, Gandhimathi R, Sivaramakrishnan S, Arunkumar M, Thangavelu T, Natarajaseenivasan K (2008) Optimization of extracellular psychrophilic alkaline lipase produced by marine Pseudomonas sp. (MSI057). Bioprocess Biosyst Eng 31:483-92. doi:10.1007/ s00449-007-0186-0

Kumar S, Kikon K, Upadhyay A, Kanwar SS, Gupta R (2005) Production, purification, and characterization of lipase from thermophilic and alkaliphilic Bacillus coagulans BTS-3. Protein Expr Purif 41:38-44. doi:10.1016/j.pep.2004.12.010

Lau HL, Ariff A, Woo KK, Ling TC, Hii SL (2011) Production and optimization of alkalostable lipase by alkalophilic Burkholderia cenocepacia ST8. African J Biotechnol 10:7002-7009. doi:10. 5897/AJB11.213

Li X, Liu T, Xu L, Gui X, Su F, Yan Y (2013) Resolution of racemic ketoprofen in organic solvents by lipase from Burkholderia cepacia G63. Biotechnol Bioprocess Eng 17: 1147-1155. doi:10.1007/s12257-012-0279-8

Lipuma JJ (2010) The changing microbial epidemiology in cystic fibrosis. Clin Microbiol Rev 23:299-323. doi:10.1128/CMR.00068-09

Liu C-H, Lu W-B, Chang J-S (2006) Optimizing lipase production of Burkholderia sp. by response surface methodology. Process Biochem 41:1940-1944. doi:10.1016/j.procbio.2006.04.013

Liu C-H, Huang C-C, Wang Y-W, Chang J-S (2012) Optimizing lipase production from isolated Burkholderia sp. J Taiwan Inst Chem Eng 43:511-516. doi:10.1016/j.jtice.2012.02.004

Lo C-F, Yu C-Y, Kuan I-C, Lee S-L (2012) Optimization of lipase production by Burkholderia sp. using response surface methodology. Int J Mol Sci 13:14889-97. doi:10.3390/ijms131114889

Mateo C, Palomo JM, Fernandez-Lorente G, Guisan JM, FernandezLafuente R (2007) Improvement of enzyme activity, stability and selectivity via immobilization techniques. Enzyme Microb Technol 40:1451-1463. doi:10.1016/j.enzmictec.2007.01.018

Oliveira BH, Lima VMG (2014) Chicken fat and inorganic nitrogen source for lipase production by Fusarium sp. (Gibberella fujikuroi complex). Afr J Biotechnol 13:1393-1401. doi:10. 5897/AJB2013.13502

Oliveira BH, Coradi GV, Attili-Angelis D, Scauri C, Luques AHP G, Barbosa AM, Dekker RFH, Oliva Neto P, Lima VMG (2013) Comparison of lipase production on crambe oil and meal by Fusarium sp. (Gibberella fujikuroi complex). Eur J Lipid Sci Technol 115:1413-1425. doi:10.1002/ejlt.201300087

Park D-S, Oh H-W, Heo S-Y, Jeong WJ, Shin DH, Bae KS, Park HY (2007) Characterization of an extracellular lipase in Burkholderia sp. HY-10 isolated from a longicorn beetle. J Microbiol 45:409-17

Pencreac'h G, Baratti JC (2001) Comparison of hydrolytic activity in water and heptane for thirty-two commercial lipase preparations. Enzyme Microb Technol 28:473-479

Pignède G, Wang HJ, Fudalej F, Seman M, Gaillardin C, Nicaud JM (2000) Autocloning and amplification of LIP2 in Yarrowia lipolytica. Appl Environ Microbiol 66:3283-9

Rathi P, Saxena R, Gupta R (2001) A novel alkaline lipase from Burkholderia cepacia for detergent formulation. Process Biochem 37:187-192. doi:10.1016/S0032-9592(01)00200-X

Soultani S, Engasser J-M, Ghoul M (2001) Effect of acyl donor chain length and sugar/acyl donor molar ratio on enzymatic synthesis of fatty acid fructose esters. J Mol Catal B Enzym 11:725-731. doi:10. 1016/S1381-1177(00)00162-4

USDA Economic Research Service (2014) http://www.ers.usda.gov/. Accessed 20 Feb 2014.

Vanlaere E, Baldwin A, Gevers D, Henry D, De Brandt E, LiPuma JJ, Mahenthiralingam E, Speert DP, Dowson C, Vandamme P (2009) Taxon K, a complex within the Burkholderia cepacia complex, comprises at least two novel species, Burkholderia contaminans sp. nov. and Burkholderia lata sp. nov. Int J Syst Evol Microbiol 59:102-11. doi:10.1099/ijs.0.001123-0

Wang H, Liu R, Lu F, Qi W, Shao J, Ma HJ (2009) A novel alkaline and low-temperature lipase of Burkholderia cepacia isolated from Bohai in China for detergent formulation. Ann Microbiol 59:105-110

Winkler UK, Stuckmann M (1979) Glycogen, hyaluronate, and some other polysaccharides greatly enhance the formation of exolipase by Serratia marcescens. J Bacteriol 138:663-70

Yang J, Guo D, Yan Y (2007) Cloning, expression and characterization of a novel thermal stable and short-chain alcohol tolerant lipase from Burkholderia cepacia strain G63. J Mol Catal B Enzym 45:91-96. doi:10.1016/j.molcatb.2006.12.007 